\title{
Teachers' Beliefs and Practices in Teaching Listening
}

\author{
Fauziana Mohd Sah, Parilah Mohd Shah \\ Education Faculty, Universiti Kebangsaan Malaysia, Bangi, Malaysia \\ Email:norfauzianamsah@gmail.com,drparila@gmail.com
}

How to cite this paper: Sah, F. M., \& Shah, P. M. (2020). Teachers' Beliefs and Practices in Teaching Listening. Creative Education, 11, 182-195.

https://doi.org/10.4236/ce.2020.112013

Received: January 29, 2020

Accepted: February 24, 2020

Published: February 27, 2020

Copyright $\odot 2020$ by author(s) and Scientific Research Publishing Inc. This work is licensed under the Creative Commons Attribution International License (CC BY 4.0).

http://creativecommons.org/licenses/by/4.0/

\begin{abstract}
English is considered one of the most important languages in the world and among all of the four skills, listening is considered the most important skill. However, listening has been neglected in the classroom and less research has been done regarding listening. The purpose of this study is to examine the beliefs and teaching practices of teaching listening towards low proficiency students. The result of this study was taken from a preliminary study, with quantitative study as the research design and questionnaire was used as the instrument. The target population of this study was $25(\mathrm{n}=25)$ Form 1,2 and 3 teachers who are teaching in five different schools in a district in Sabah, Malaysia. The findings suggest that most teachers believe that the lack of vocabulary among students is the biggest obstacle for students in learning listening comprehension. The study also suggests that most teachers often practice direct instruction and drilling in teaching listening comprehension. The result of this study should be able to help teachers reflect on their beliefs and how it is shown through their teaching practices. It also can help teachers to understand better the teaching of listening to improve their teaching skills. It is suggested that more research need to be done in the area of listening comprehension in Malaysian schools.
\end{abstract}

\section{Keywords}

Listening, Listening Comprehension, Teaching Beliefs, Teaching Practices, ESL

\section{Introduction}

English is considered one of the most important languages to be mastered as it is deemed as the world's lingua franca and is spoken by 1.5 billion people all over the world by the year 2000 (Crystal, 2003). To master English, one has to master 
all of the four skills which are reading, writing, listening and speaking. Among all of the four skills, listening is considered the most important skill as learners require $45 \%$ of language competence from listening (Renukadevi, 2014). However, despite its importance, listening skill is the most neglected in the classroom (Hamouda, 2013). Aside from that, listening also is the least researched among all of the four skills (Khuziakhmetov \& Porchesku, 2016; Vandergrift, 2007). In the Malaysian context, the study in teaching listening is also very limited and most of the studies have been done in the higher institution level (Deepak, Noriah, Norhuda, Nur Aza, \& Umi Farradilla, n.d.; Kuen \& Embi, 2012; Tahsildar \& Yusoff, 2014; Nur Sakinah \& Nooreen, 2013) and fewer were done in the secondary or primary level (Lim, 2013; Appukuttan, 2013). Therefore, this study aims to contribute to the knowledge of teachers' belief in teaching listening to not only the Malaysian education field but also in teaching listening as a whole. Specifically, this study wants to investigate teacher's beliefs and teaching practices in teaching listening comprehension Thus, it attempts to answer the following research questions: 1) What are teachers' beliefs in teaching listening comprehension?; 2) What are teachers' teaching practices in teaching listening comprehension?

\section{Literature Review}

Goss (1982) defined listening as a process of receiving what is heard and analysing in into verbal units where meaning is then applied. Thomlison (1984) and Hamouda (2013) on the other hand define listening as the capability to "identify and understand what others are saying" which include aspects such as speakers' accent and pronunciation, grammar, vocabulary and comprehension of meaning. Listening comprehension on the other hand involves listeners to have a clear concept or understanding in their schemata in reference to what the speaker have uttered, be it the same reference or not from the speakers' perspective (Rost, 2002). This means, if the listener cannot relate to anything that the speaker is saying and link it to any reference in the listener's memory, then listening comprehension is not achieved. Therefore, the development of listening comprehension skill is pertinent as it assists learners to succeed in language learning and improve their comprehensible input (Ahmadi, 2016). According to Anderson (2009), there are three stages in listening comprehension: 1) Perceptual; 2) Parsing; and 3) Utilisation. The perceptual stage is when the listeners encode the language heard. Parsing is when the encoded words are then transformed into a mental representation of the overall meaning of the words. Then finally, in the utilisation process, the listener would use the mental representation of the sentence's meaning and react appropriately towards the sentence heard.

Listening comprehension is considered the heart of language learning but the most difficult skill to learn (Kurita, 2012; Renandya \& Farrell, 2011). A study by Graham (2006) highlighted that among all of the area in language, learners find 
themselves to be least successful in listening. Coping with speed of delivery, making out individual words, making sense of identified or understood words, own supposed low ability and the difficulty of the listening tasks are the identified difficulties faced by her respondents. In making students becoming a good listener, the responsibility lies on the teachers' shoulders (Aryana \& Apsari, 2018). From the teachers' perspective, listening has the least emphasis in class. Yongbai (1992) listed three reasons why this is happening. Firstly, it is because teachers perceive teaching listening as only playing an audio and give a set of questions to answer. Secondly, teachers believe that it is hard to evaluate the progress in listening skills as it cannot be seen, unlike reading or writing. Lastly, most teachers believe that listening skills can be acquired automatically whenever speaking is practiced.

Before the implementation of Pentaksiran Tingkatan Tiga (PT3) (Form Three Assessment), the emphasis in teaching for the lower form (Form 1,2 and 3) is slightly more to reading and writing as only these two skills were being tested in Penilaian Menengah Rendah (PMR) or Lower Form Assessment. According to the Curriculum Specifications for English Form 3 (2003), both speaking and listening did not appear as discrete items in the syllabus or in all Curriculum Specification for English but are integrated into the areas of language use. In other words, it is not heavily emphasized but teachers need to incorporate them in their lesson nevertheless, depending on the theme and content of their lesson. The problem lies when teachers are drilling students to prepare them for PMR examination, which tested only on students' writing and reading, and therefore overlook the teaching of listening and speaking skills. In 2014, there was a reform in the examination format and PMR was changed to PT3. Under this new form of assessment, listening and speaking skills have started to be included to be assessed in the examination. After six years of the integration of these two skills in the assessment, it is crucial to know teachers' beliefs in teaching them as investigating teachers' beliefs and how they affect their teaching practices is important in teachers' development (Tatto, 1998). It is also important as understanding teachers' actions are essential in sustaining any reform (Tobin \& McRobbie, 1996).

According to researches, teachers' belief is very important as it helps them to construct their actions and practice in the classroom (Aksoy, 2015; Donaghue, 2003; Johnson, 1992; Kutálková, 2017; Spawa \& Hassan, 2013). According to Basturkmen et al. (2004), teaching beliefs are statements teachers made about their ideas, thoughts, and knowledge that are expressed as evaluations of what "should be done", "should be the case", and "is preferable". It is important to make teachers aware of their teaching beliefs as beliefs about language learning is the most important step to make positive change in classroom visible (Utami, 2016). Besides that, it can help them reassess their action and decisions in class when they are confronted with student failure (Rose \& Medway, 1981).

One of the most important aspects that is always related to teaching beliefs is 
teaching practice. Teaching practice is the reflections of what is working inside teachers' mind which they perceive to be true conception about language learning (Utami, 2016). What teachers believe will be expressed in realities as these concepts will influence their decision making and instructional classroom practices. There are a lot of researches that claims that teachers' beliefs do not go hand in hand with their teaching practice (Graham, Santos, \& Francis-Brophy, 2014; Li, 2013; Richardson, Anders, Tidwell, \& Lloyd, 1991; Spawa \& Hassan, 2013; Wilkins, 2008). On the other hand, there are also some studies that found teachers' teaching beliefs affect teachers' teaching practices (Farrell \& Ives, 2014; Inceçay, 2011).

\section{Methodology}

This research employs the survey design by using questionnaire as the instrument with the aim to identify the correlation between teachers' beliefs and teaching practices in teaching listening comprehension. The result of this research was taken from a preliminary study conducted at five schools in a district in Sabah, Malaysia. The respondents were $25(n=25)$ English teachers who teach the lower form (Form 1, 2 and 3). After permission was granted by the Ministry of Education (2003), State Education Department as well as the schools' administrators, the questionnaire was then distributed through the respective school's English panels.

The instrument of this study was adapted and adopted from a few studies (Choi, 1999; Gleason, 1993; Graham et al., 2014). The questionnaire was divided into three sections. Demographic section, Section B which is for teaching beliefs and Section $C$ is for teaching practices. Items for section B are derived from Gleason (1993) (item 1 - 13) and Graham et al. (2014) (item 14 - 18) while items for Section C are derived from Gleason (1993) (item 1 - 12) and Choi (1999) (item 13 - 17). Statistical Package for the Social Sciences (SPPS) software version 23 was used to analyse the data.

\section{Findings}

This research has answered two research questions. The findings of this study are discussed in the following questions.

\subsection{What Are the Teachers' Beliefs in Teaching Listening Comprehension?}

The first research question is "What are teachers' beliefs in teaching listening?". There are 18 question items asked under this research question. The scales used for this research question are Strongly Disagree (SD), Disagree (D), Not Sure (NS), Agree (A), and Strongly Agree (SA). The results are as according to Table 1.

The findings revealed that most teachers (57.7\%) agree that they know how to check for listening comprehension with their students while $19.2 \%$ strongly agree. However, $23.1 \%$ teachers are not sure on how to do so. All teachers either 
Table 1. Beliefs in teaching listening.

\begin{tabular}{|c|c|c|c|c|c|c|}
\hline No & Item & $\begin{array}{c}\text { SD } \\
\%(n)\end{array}$ & $\begin{array}{c}D \\
\%(n)\end{array}$ & $\begin{array}{c}\mathrm{N} \\
\%(\mathrm{n})\end{array}$ & $\begin{array}{c}\mathrm{A} \\
\%(\mathrm{n})\end{array}$ & $\begin{array}{c}\text { SA } \\
\%(n)\end{array}$ \\
\hline 1 & I know how to check for listening comprehension in my students. & 0 & 0 & $\begin{array}{c}23.1 \\
(6)\end{array}$ & $\begin{array}{l}57.7 \\
(15)\end{array}$ & $\begin{array}{c}19.2 \\
(5)\end{array}$ \\
\hline 2 & Listening is a basic skill. & 0 & 0 & 0 & $\begin{array}{l}53.8 \\
(14)\end{array}$ & $\begin{array}{l}46.2 \\
(12)\end{array}$ \\
\hline 3 & $\begin{array}{l}\text { If teachers spend more time teaching listening skills, students would be able to work in } \\
\text { more advanced content and skills at an earlier age. }\end{array}$ & 0 & $\begin{array}{l}7.7 \\
(2)\end{array}$ & $\begin{array}{c}15.4 \\
(4)\end{array}$ & $\begin{array}{l}53.8 \\
(14)\end{array}$ & $\begin{array}{c}23.1 \\
(6)\end{array}$ \\
\hline 4 & Students should do more talking and less listening to the teacher. & $\begin{array}{l}7.7 \\
(2)\end{array}$ & $\begin{array}{l}38.5 \\
(10)\end{array}$ & $\begin{array}{c}11.5 \\
(3)\end{array}$ & $\begin{array}{c}23.1 \\
(6)\end{array}$ & $\begin{array}{c}19.2 \\
(5)\end{array}$ \\
\hline 5 & The teaching of listening skills is the responsibility of every teacher. & $\begin{array}{l}3.8 \\
(1)\end{array}$ & $\begin{array}{l}3.8 \\
(1)\end{array}$ & $\begin{array}{l}3.8 \\
(1)\end{array}$ & $\begin{array}{l}57.7 \\
(15)\end{array}$ & $\begin{array}{c}30.8 \\
(8)\end{array}$ \\
\hline 6 & I have explicit preparation for the teaching of listening skills. & 0 & $\begin{array}{c}19.2 \\
(5)\end{array}$ & $\begin{array}{c}11.5 \\
(3)\end{array}$ & $\begin{array}{l}61.5 \\
(16)\end{array}$ & $\begin{array}{l}7.7 \\
(2)\end{array}$ \\
\hline 7 & Listening skills are lacking in my students. & 0 & $\begin{array}{c}15.4 \\
(4)\end{array}$ & $\begin{array}{c}15.4 \\
(4)\end{array}$ & $\begin{array}{l}46.2 \\
(12)\end{array}$ & $\begin{array}{c}23.1 \\
(6)\end{array}$ \\
\hline 8 & $\begin{array}{l}\text { Listening is the most important area among the four language arts (reading, speaking, } \\
\text { writing and listening). }\end{array}$ & $\begin{array}{l}3.8 \\
(1)\end{array}$ & $\begin{array}{c}26.9 \\
(7)\end{array}$ & $\begin{array}{l}34.6 \\
(9)\end{array}$ & $\begin{array}{c}23.1 \\
(6)\end{array}$ & $\begin{array}{c}11.5 \\
(3)\end{array}$ \\
\hline 9 & Listening is a skill that can be taught. & 0 & 0 & $\begin{array}{c}11.5 \\
(3)\end{array}$ & $\begin{array}{l}65.4 \\
(17)\end{array}$ & $\begin{array}{c}23.1 \\
(6)\end{array}$ \\
\hline 10 & $\begin{array}{l}\text { To enhance listening skills and attitudes, less time should be devoted to discussing } \\
\text { questions and answers from the text and more time should be devoted to group } \\
\text { discussion and problem solving to enhance listening skills. }\end{array}$ & $\begin{array}{l}3.8 \\
(1)\end{array}$ & $\begin{array}{c}15.4 \\
(4)\end{array}$ & $\begin{array}{c}26.9 \\
(7)\end{array}$ & $\begin{array}{l}38.5 \\
(10)\end{array}$ & $\begin{array}{c}15.4 \\
(4)\end{array}$ \\
\hline 11 & The main difficulties for learners in listening arise from lack of grammatical knowledge. & $\begin{array}{c}11.5 \\
(3)\end{array}$ & $\begin{array}{c}23.1 \\
(6)\end{array}$ & $\begin{array}{l}7.7 \\
(2)\end{array}$ & $\begin{array}{l}34.6 \\
(9)\end{array}$ & $\begin{array}{c}23.1 \\
(6)\end{array}$ \\
\hline 12 & More emphasis needs to be placed on the role of listening in the learning process. & 0 & $\begin{array}{l}3.8 \\
(1)\end{array}$ & $\begin{array}{l}34.6 \\
(9)\end{array}$ & $\begin{array}{l}38.5 \\
(10)\end{array}$ & $\begin{array}{c}23.1 \\
(6)\end{array}$ \\
\hline 13 & $\begin{array}{l}\text { Raising the quality of children's listening skills and attitudes affects their learning } \\
\text { positively in all subject areas. }\end{array}$ & 0 & 0 & $\begin{array}{l}11.5 \\
(3)\end{array}$ & $\begin{array}{l}53.8 \\
(14)\end{array}$ & $\begin{array}{c}34.6 \\
(9)\end{array}$ \\
\hline 14 & $\begin{array}{l}\text { The main difficulties for learners in listening arise from the background knowledge about } \\
\text { the topic of the passage. }\end{array}$ & 0 & $\begin{array}{l}11.5 \\
(3)\end{array}$ & $\begin{array}{c}11.5 \\
(3)\end{array}$ & $\begin{array}{c}50 \\
(13)\end{array}$ & $\begin{array}{c}26.9 \\
(7)\end{array}$ \\
\hline 15 & The main difficulties for learners in listening arise from their lack of vocabulary. & 0 & 0 & 0 & $\begin{array}{l}34.6 \\
(9)\end{array}$ & $\begin{array}{l}65.4 \\
(17)\end{array}$ \\
\hline 16 & $\begin{array}{l}\text { When learners don't understand a word, they should work out its meaning from the } \\
\text { context. }\end{array}$ & 0 & $\begin{array}{l}3.8 \\
(1)\end{array}$ & 0 & $\begin{array}{l}69.2 \\
(18)\end{array}$ & $\begin{array}{c}26.9 \\
(7)\end{array}$ \\
\hline 17 & After listening, students should discuss how they completed the listening activity. & 0 & 0 & $\begin{array}{c}15.4 \\
(4)\end{array}$ & $\begin{array}{l}53.8 \\
(14)\end{array}$ & $\begin{array}{c}30.8 \\
(8)\end{array}$ \\
\hline 18 & It is possible to teach learners how to listen more effectively. & 0 & $\begin{array}{l}3.8 \\
(1)\end{array}$ & $\begin{array}{l}7.7 \\
(2)\end{array}$ & $\begin{array}{l}61.5 \\
(16)\end{array}$ & $\begin{array}{c}26.9 \\
(7)\end{array}$ \\
\hline
\end{tabular}

agree $(53.8 \%)$ and strongly agree $(46.2 \%)$ that listening is a basic skill. A percentage of $7.7 \%$ teachers disagree that if teachers spend more time teaching listening skills, students would be able to work in more advance content and skills at earlier age while $15.4 \%$ are not sure. The rest of the respondents agree (53.8\%) and strongly agree $(23.1 \%)$. 
It is also found that less respondents believe students should do more talking than listening in class (23.1\% agree and $19.2 \%$ strongly agree) and more respondents believe the opposite ( $7.7 \%$ strongly disagree and $38.5 \%$ disagree), while a few of them are not sure (11.5\%). In terms of the teaching of listening being the responsibility of every teacher, $57.7 \%$ respondents agree and $30.8 \%$ strongly agree, while other responses each have 3.8\% (strongly disagree, disagree and not sure). For the teaching of listening skills, $61.5 \%$ agree and $7.7 \%$ strongly agree that they have explicit preparation. However, 19.2\% respondents disagree and $11.5 \%$ respondents are not sure if they have prepared explicitly or not.

A total of $69.3 \%$ ( $46.2 \%$ agree and $23.1 \%$ strongly agree) believe that their students lack listening skills while $15.4 \%$ respondents disagree. Another $15.4 \%$ respondents are not sure if their students lack listening skills. The majority of the respondents (34.6\%) are not sure if listening is the most important area among the four skills. A small number of $3.8 \%$ from the respondents strongly disagree and $15.4 \%$ disagree that listening is the most important area. On the other hand, $23.1 \%$ respondents agree and $11.5 \%$ respondents strongly agree.

A total of $88.5 \%$ (65.4\% agree and $23.1 \%$ strongly agree) that listening is a skill that can be taught and only $11.5 \%$ respondents are not sure if it can be taught or not. Next, $38.5 \%$ respondents agree and $15.4 \%$ strongly agree that more time should be devoted to group discussion and problem solving to enhance listening skills while $3.8 \%$ strongly disagree and $15.4 \%$ disagree. The remaining $26.9 \%$ are not sure about this matter. A percentage of $11.5 \%$ strongly disagree and $23.1 \%$ disagree that grammatical knowledge is the main difficulty for learners in listening while a bigger percentage ( 34.6 agree and $23.1 \%$ strongly agree) believe the opposite. The balance of $7.7 \%$ of gave the response of not sure. When talking about the role of listening, $38.5 \%$ agree and $23.1 \%$ strongly agree that it needs to be emphasised in the listening process. A number of $34.6 \%$ however are not sure and only $3.8 \%$ disagree on this matter. A large percentage of respondents (88.4\%) believe that raising the quality of children's listening skills and attitude affects their learning positively in all subjects with $53.8 \%$ agree and $34.6 \%$ disagree.

Majority of the respondents believe that the main difficulty in listening is from the background knowledge about the topic or passage being used in listening with $50 \%$ agree and $26.9 \%$ strongly agree. The remaining $23 \%$ are divided equally between not sure and disagree. All of the respondents believe that the main difficulty in listening is due to the lack of vocabulary among students with $34.6 \%$ agree ad $65.4 \%$ strongly agree. Most respondents also believe that learners should work out its meaning from the context when they don't understand a word with $69.2 \%$ agree and $26.9 \%$ strongly agree. Only the remain of $3.8 \%$ disagree on this matter. On the matter of should or should not learners discuss on how they complete the listening activity after the activity is completed, $53.8 \%$ agree and $30.8 \%$ strongly agree while $15.4 \%$ are not sure. And finally, most of the respondents (61.5\% agree and $26.9 \%$ strongly agree) believe that it is possible to 
teach learners how to listen effectively. Only 3.8\% disagree and another $7.7 \%$ are not sure whether it is possible or not.

\subsection{What Are the Teachers' Teaching Practices in Teaching Listening Comprehension?}

The second research question is "What are teachers' teaching practices in teaching listening?". There are 17 question items asked under this research question. The scale used for this research question are Never (N), Rarely (R), Sometimes $(\mathrm{S})$, Often $(\mathrm{O})$, and Always (A). The results are as according to Table 2.

Table 2. What are the teachers' teaching practices in teaching listening comprehension?

\begin{tabular}{|c|c|c|c|c|c|c|}
\hline No & Item & $\begin{array}{c}\mathrm{N} \\
\%(\mathrm{n})\end{array}$ & $\begin{array}{c}\mathrm{R} \\
\%(\mathrm{n})\end{array}$ & $\begin{array}{c}S \\
\%(n)\end{array}$ & $\begin{array}{c}\mathrm{O} \\
\%(\mathrm{n})\end{array}$ & $\begin{array}{c}\text { A } \\
\%(n)\end{array}$ \\
\hline 1 & Listening skills and attitudes are taught by direct instruction in my classroom. & $\begin{array}{l}3.8 \\
(1)\end{array}$ & 0 & $\begin{array}{c}26.9 \\
(7)\end{array}$ & $\begin{array}{l}57.7 \\
(15)\end{array}$ & $\begin{array}{c}11.5 \\
(3)\end{array}$ \\
\hline 2 & Purposes for listening are suggested and developed with my students. & 0 & $\begin{array}{l}3.8 \\
(1)\end{array}$ & $\begin{array}{c}30.8 \\
(8)\end{array}$ & $\begin{array}{l}50.0 \\
(13)\end{array}$ & $\begin{array}{c}15 . .4 \\
(4)\end{array}$ \\
\hline 3 & Give my students a specific goal or task to accomplish while listening. & 0 & 0 & $\begin{array}{c}30.8 \\
(8)\end{array}$ & $\begin{array}{l}42.3 \\
(11)\end{array}$ & $\begin{array}{c}26.9 \\
(7)\end{array}$ \\
\hline 4 & $\begin{array}{l}\text { I focus on how well a student listens rather than his/her knowledge of listening skills and } \\
\text { attitudes. }\end{array}$ & $\begin{array}{l}3.8 \\
(1)\end{array}$ & $\begin{array}{c}11.5 \\
(3)\end{array}$ & $\begin{array}{c}34.5 \\
(9)\end{array}$ & $\begin{array}{l}38.5 \\
(10)\end{array}$ & $\begin{array}{c}11.5 \\
(3)\end{array}$ \\
\hline 5 & Visual aids are used in my classroom when I teach listening skills. & 0 & $\begin{array}{l}3.8 \\
(1)\end{array}$ & $\begin{array}{l}46.2 \\
(12)\end{array}$ & $\begin{array}{l}42.3 \\
(11)\end{array}$ & $\begin{array}{l}7.7 \\
(2)\end{array}$ \\
\hline 6 & $\begin{array}{l}\text { Listening to acquire new information and insure an understanding of it accompanies most } \\
\text { listening experiences in my classroom. }\end{array}$ & 0 & 0 & $\begin{array}{c}30.8 \\
(8)\end{array}$ & $\begin{array}{l}53.8 \\
(14)\end{array}$ & $\begin{array}{c}15.4 \\
(4)\end{array}$ \\
\hline 7 & $\begin{array}{l}\text { I teach nonverbal communication (for example, body language, tonality, etc.) in } \\
\text { conjunction with listening skills. }\end{array}$ & $\begin{array}{l}3.8 \\
(1)\end{array}$ & $\begin{array}{c}11.5 \\
(3)\end{array}$ & $\begin{array}{c}26.9 \\
(7)\end{array}$ & $\begin{array}{l}42.3 \\
(11)\end{array}$ & $\begin{array}{c}15.4 \\
(4)\end{array}$ \\
\hline 8 & Students in my classroom learn the role of the listener in the communication process. & $\begin{array}{l}3.8 \\
(8)\end{array}$ & $\begin{array}{c}30.8 \\
(8)\end{array}$ & $\begin{array}{l}50.0 \\
(13)\end{array}$ & $\begin{array}{c}15.4 \\
(4)\end{array}$ & 0 \\
\hline 9 & $\begin{array}{l}\text { As students in my classroom develop listening skills, classroom activities emphasize their } \\
\text { use in everyday situations. }\end{array}$ & 0 & 0 & $\begin{array}{c}30.8 \\
(8)\end{array}$ & $\begin{array}{c}50 \\
(13)\end{array}$ & $\begin{array}{c}19.2 \\
(5)\end{array}$ \\
\hline 10 & Auditory aids are used in my classroom when I teach listening skills. & $\begin{array}{l}3.8 \\
(1)\end{array}$ & $\begin{array}{c}11.5 \\
(3)\end{array}$ & $\begin{array}{l}34.6 \\
(9)\end{array}$ & $\begin{array}{l}42.3 \\
(11)\end{array}$ & $\begin{array}{l}7.7 \\
(2)\end{array}$ \\
\hline 11 & I create a classroom environment conducive to listening. & 0 & $\begin{array}{l}3.8 \\
(1)\end{array}$ & $\begin{array}{l}38.5 \\
(10)\end{array}$ & $\begin{array}{c}50 \\
(13)\end{array}$ & $\begin{array}{l}7.7 \\
(2)\end{array}$ \\
\hline 12 & Design lesson plans with activities and games that encourage listening. & 0 & $\begin{array}{c}11.5 \\
(3)\end{array}$ & $\begin{array}{c}23.1 \\
(6)\end{array}$ & $\begin{array}{l}53.8 \\
(14)\end{array}$ & $\begin{array}{c}11.5 \\
(3)\end{array}$ \\
\hline 13 & I use teacher lecture-type explanation (teacher-centred) when teaching listening. & 0 & $\begin{array}{c}15.4 \\
(4)\end{array}$ & $\begin{array}{l}38.5 \\
(10)\end{array}$ & $\begin{array}{c}30.8 \\
(8)\end{array}$ & $\begin{array}{c}15.4 \\
(4)\end{array}$ \\
\hline 14 & $\begin{array}{l}\text { I use learner-centred activities; learner-initiated activities, topics and activities selected by } \\
\text { learners, and activities among students when teaching listening. }\end{array}$ & 0 & $3.8(1)$ & $\begin{array}{l}46.2 \\
(12)\end{array}$ & $\begin{array}{l}42.3 \\
(11)\end{array}$ & $\begin{array}{l}7.7 \\
(2)\end{array}$ \\
\hline 15 & I use authentic audio materials in teaching listening (e.g. movies. videos, songs, podcasts). & 0 & $\begin{array}{r}26.9 \\
(7)\end{array}$ & $\begin{array}{c}30.8 \\
(8)\end{array}$ & $\begin{array}{l}38.5 \\
(10)\end{array}$ & $\begin{array}{l}3.8 \\
(1)\end{array}$ \\
\hline 16 & I use English for classroom instruction to train students' listening skills. & 0 & 0 & $\begin{array}{c}30.8 \\
(8)\end{array}$ & $\begin{array}{l}50.0 \\
(13)\end{array}$ & $\begin{array}{c}19.2 \\
(5)\end{array}$ \\
\hline 17 & I teach Listening by drilling (e.g. exercises from workbook). & 0 & $\begin{array}{l}3.8 \\
(1)\end{array}$ & $\begin{array}{c}34.6 \\
(9)\end{array}$ & $\begin{array}{l}46.2 \\
(12)\end{array}$ & $\begin{array}{c}15.4 \\
(4)\end{array}$ \\
\hline
\end{tabular}


From Table 2, it can be seen that $57.7 \%$ often and $11.5 \%$ respondent always teach listening skills and attitudes by direct instruction in the classroom while $26.9 \%$ teachers sometimes do so and 3.8\% teachers have never done so. Nearly all respondents suggested and developed purposes for listening in the classroom with $30.8 \%$ sometimes do so, $50 \%$ often and $15.4 \%$ always do so in their class. A number of $30.8 \%$ respondents sometimes give students specific goals or tasks to accomplish while listening while $42.3 \%$ often do so and another $26.9 \%$ always.

In terms on focusing on how well students listen rather than their knowledge of listening skills, $3.8 \%$ respondents admit have never done so and $11.5 \%$ rarely do so in class. A percentage of $34.5 \%$ respondents however sometimes do focus on how well students listen rather than their knowledge of listening skills while $38.5 \%$ often do so while another $11.5 \%$ always do so. Nearly half of the respondents $(46.2 \%)$ sometimes use visual aids when teaching listening while the rest often or always do so ( $42.3 \%$ often and $7.7 \%$ always). All respondents also conduct their listening lessons by listening to acquire new information and make sure students understand the nearly acquired knowledge (30.8\% sometimes, $53.8 \%$ often and $15.4 \%$ always). When talking about teaching non-verbal communication while teaching listening skills, 3.8\% teachers admit to have never done it in class while $11.5 \%$ rarely do it. A percentage of $26.9 \%$ respondents sometimes do teach non-verbal communication while a total of $57.7 \%$ respondents often and always teach non-verbal communication while teaching listening (42.3\% often and $15.4 \%$ always).

Half of the respondents (50\%) sometimes teach students the role of a listener in a communication process. On the other hand, 3.8\% respondents have never taught and $11.5 \%$ rarely teach their students on listeners' role in the communication process. Only $15.4 \%$ respondents always teach their students. All teachers conduct classroom activities that emphasize the use of listening skills in students' daily situations when the students develop their listening skills $(30.8 \%$ sometimes, $50 \%$ often and $19.2 \%$ always). It is found that $3.8 \%$ respondents have never used and $11.5 \%$ respondents rarely use auditory aids when teaching listening. The rest of the respondents either sometimes (34.6\%), often (42.3\%) and always $(7.7 \%)$ use auditory aids in their class when teaching listening. In terms of creating a classroom environment conducive to listening, 50\% respondents responded that they often do so, followed by $38.5 \%$ who sometimes do and $7.7 \%$ who always do. Only a small percentage of the respondents (3.8\%) rarely create conducive environment for listening.

When it comes to designing lesson plans with activities and games that encourage listening, the majority (53.8\%) of the respondents often do so, followed by $23.1 \%$ who sometimes do so and the same number of percentage $(11.5 \%)$ of respondents who always and rarely do so. Most of the respondents (38.5\%) admit they sometimes use teacher-lecture type explanation while teaching listening while $38.8 \%$ of them often and $15.4 \%$ always do so. Only $3.8 \%$ respondents rarely use teacher-lecture type explanation when teaching listening. A percent- 
age of $7.7 \%$ respondents responded that they always use learner-centred activities in their listening class. $42.3 \%$ respondents often use learner-centred activities and $46.2 \%$ sometimes do. A small percentage of $3.8 \%$ respondents rarely use learner-centred activities. Most of the respondents either rarely (26.9\%) or sometimes (30.8\%) use authentic audio materials in their lesson while $38.5 \%$ often and 3.8\% always. 30.8\% respondents admitted that they sometimes use English for classroom instruction to train students' listening skills. The rest $69.2 \%$ are either often (50\%) or always (19.2\%) use English for classroom instruction. Lastly, $15.4 \%$ respondents always and $46.2 \%$ respondents often teach listening by drilling. $34.6 \%$ respondents sometimes do so and $3.8 \%$ rarely do.

\section{Discussion}

For teachers' beliefs, most of the respondents choose "agree" and "strongly agree" for their answer. Highest percentage for "strongly agree" that reaches 50\% or more is for the item "the main difficulties for learners in listening arise from their lack of vocabulary" (65.4\%). This result aligns with the result of a study by Renandya and Farrell (2011) and Gilakjani \& Sabouri (2016) where vocabulary was listed as one of the source of students listening problems. Japanese students too have the same problem as they are unable to recognize target words or sentence while listening (Hamada, 2015). The highest percentage for "agree" that reaches $50 \%$ or more are "I know how to check for listening comprehension in my students", "listening is a basic skill", "if teachers spend more time teaching listening skills, students would be able to work in more advanced content and skills at an earlier age", "the teaching of listening skills is the responsibility of every teacher", "I have explicit preparation for the teaching of listening skills", "listening is a skill that can be taught", "raising the quality of children's listening skills and attitudes affects their learning positively in all subject areas", "the main difficulties for learners in listening arise from the background knowledge about the topic of the passage", "when learners don't understand a word, they should work out its meaning from the context", and "after listening, students should discuss how they completed the listening activity". Most of the items listed here are on teachers' confidence in their ability of teaching listening and believing that listening skills can be taught and trained. This result shows how confident teachers are in teaching listening comprehension despite listening being a difficult skill to be taught as it is considered as a "passive" skill i.e. a skill that mostly happens in learners' mind (Field, 2008).

The respondents in this study believe the importance of a teacher's role in teaching listening and this can be seen reflected from the findings whereby most of the items mentioned that get $50 \%$ or above "agree" are about teachers' confidence in their teaching skills and how listening skills can be taught and trained. This is in line with what was mentioned by Harmer (2001) whereby there are eight roles of a teacher in a class which are a controller, organiser, assessor, prompter, participant, resource, tutor and observer. When teachers are confi- 
dent enough in their skills, they can easily play their roles as needed by the students.

The item that gains the highest "strongly disagree" rate is "the main difficulties for learners in listening arise from lack of grammatical knowledge". A research done by Goh (1999) uncovers the five most common factors that influence students' listening comprehension which are vocabulary, prior knowledge, speech rate, type of input and speaker's accent. Lack of grammatical knowledge was not listed. Goh's findings also support this research's findings mentioned earlier where the majority of teachers believe students' lack of vocabulary as the main factor that contributes to the difficulty in listening comprehension.

For teaching practices, it is found that most respondents responded either "sometimes" or "often", with "often" having the most items that score more than $50 \%$. Most teachers often "suggest and develop purposes of listening with their students", "accompanies most listening experience in class with listening to acquire new information", and "design lesson plan with activities and games that encourage listening". These findings show that in terms of their teaching purpose, teachers focus more on helping students change their attitude towards listening alongside with teaching the listening skill, instead of only focusing on the listening skills. As Graham (2006) stated, it is imperative not only to teach students on how to listen but also their beliefs on listening comprehension and them as listeners.

Field (2008) explained how teachers nowadays have the same wrong assumption in teaching listening, which is leaners become better listener by the number of their listening experience i.e. exercises or practices. Teachers become obsessed on students' right or wrong answers instead of helping them develop on the skills that can help them avoid the same mistake in the future. This wrong assumption by teachers can be seen reflected from this research where $57.7 \%$ often and $11.5 \%$ always teach listening skills and attitudes through direct instruction, nearly $50 \%$ of the respondents teach listening by drilling and $30.8 \%$ respondents rarely teach students their role as a listener in the communication process. This result is the same with the teaching practices by teachers in England from the result of a study by Santos \& Graham (2018) in which their study compares the teaching practices between teachers in Brazil and England. In their study, it is found that teachers in Brazil focus more on comprehension or understanding whereas teachers in England focus more on answering questions correctly. This kind of focus can make learners feel they could not take control over their learning and that it is impossible to build up their listening skills (Graham, 2006).

This research shows us what are the beliefs of teachers and the teaching practices in teaching listening comprehension. Overall, the majority of the respondents mostly choose "agree" and disagree' for teachers' beliefs with the highest percentage of respondents believe that "students should make out the meaning of a words they don't understand from the context", For teaching practices, this 
study reveals that most respondents choose "sometimes" and "often" for the items under teaching practices with the majority of the respondents always "teach listening skills and attitude using direct instruction in class".

\section{Conclusion}

The findings of this study suggest that teachers do believe their students are lacking in listening skills and one of the biggest barriers they have in listening comprehension is their lack of vocabulary. On the other hand, teachers are confident that listening skills can be taught and are confident with their ability to teach them. With regards to teaching practices, most teachers teach listening comprehension through direct instruction and drilling and less often use authentic materials or explain about the role of listener during listening comprehension. This shows how most teachers believe that listening skills can be acquired after students have gone under plenty of listening exercises.

The findings of this study can help teachers to understand better their teaching beliefs and teaching practices in class which could help identify their strengths and weaknesses in teaching listening comprehension and thus improve themselves for better and effective lessons. For example, by learning that most teachers identify vocabulary as the challenge in listening, teachers can now conduct lesson plans that could help students to improve their vocabulary. It is suggested for future researchers to investigate teachers' beliefs and practices through the qualitative lens to enrich more literature in this field as there is very limited research that has been done on listening, especially in Malaysia.

\section{Conflicts of Interest}

The authors declare no conflicts of interest regarding the publication of this paper.

\section{References}

Ahmadi, S. M. (2016). The Importance of Listening Comprehension in Language Learning. International Journal of Research in English Education, 1, 7-10.

Aksoy, K. (2015). What You Think Is Not What You Do in the Classroom: Investigating Teacher's Beliefs for Classroom Management in an EFL Classroom. Procedia-Social and Behavioral Sciences, 199, 675-683. https://doi.org/10.1016/j.sbspro.2015.07.597

Anderson, J. R. (2009). Cognitive Psychology and Its Implications (7th ed.). New York: Worth Publishers.

Appukuttan, S. (2013). ESL Pupils' Attitude and Motivation towards Speaking in English Language. Doctoral Dissertation, Universiti Teknologi Malaysia.

Aryana, S., \& Apsari, Y. (2018). Analyzing Teacher's Difficulties in Teaching Listening. Journal of English Language Teaching in Indonesia, 6, 100-106. http://e-journal.stkipsiliwangi.ac.id/index.php/eltin/article/view/1132/722 https://doi.org/10.22460/eltin.v6i2.p100-106

Basturkmen, H., Loewen, S., \& Ellis, R. (2004). Teachers' Stated Beliefs about Incidental Focus on Form and Their Classroom Practices. Applied Linguistics, 25, 243-272. https://doi.org/10.1093/applin/25.2.243 
Choi, S. (1999). Teaching English as a Foreign Language in Korean Middle Schools: Exploration of Communicative Language Teaching through Teachers'Beliefs and Self-Reported Classroom Teaching Practices. Columbus, $\mathrm{OH}$ : The Ohio State University.

Crystal, D. (2003). English as a Global Language (2nd ed.). New York: Cambridge University Press. https://doi.org/10.1017/CBO9780511486999

Deepak, S., Noriah, I., Norhuda, A., Nur Aza, K., \& Umi Farradilla, A. G. (n.d.). Achievement in the Malaysian University English Test (MUET) in Relationship to Learners' Informal Exposure to English.

Donaghue, H. (2003). An Instrument to Elicit Teachers' Beliefs and Assumptions. ELT Journal, 57, 344-351. https://doi.org/10.1093/elt/57.4.344

Farrell, T. S. C., \& Ives, J. (2014). Exploring Teacher Beliefs and Classroom Practices through Reflective Practice: A Case Study. Language Teaching Research, 19, 594-610. https://doi.org/10.1177/1362168814541722

Field, J. (2008). Listening in the Language Classroom. Cambridge: Cambridge University Press.

Gilakjani, A. P., \& Sabouri, N. B. (2016). Learners' Listening Comprehension Difficulties in English Language Learning: A Literature Review. English Language Teaching, 9, 123-133. https://doi.org/10.5539/elt.v9n6p123

Gleason, M. L. (1993). The Teaching of Listening in the Elementary School. Doctoral Dissertation, University of South Dakota.

Goh, C. (1999). How Much Do Learners Know about the Factors That Influence Their Listening Comprehension? Hong Kong Journal of Applied Linguistics, 4, 17-42. https://pdfs.semanticscholar.org/ee28/87c82a7d39405935bdaabc040f6cfba57efb.pdf

Goss, B. (1982). Listening as Information Processing. Communication Quarterly, 30, 304-307. https://doi.org/10.1080/01463378209369465

Graham, S. (2006). Listening Comprehension: The Learners' Perspective. System, 34, 165-182. https://doi.org/10.1016/j.system.2005.11.001

Graham, S., Santos, D., \& Francis-Brophy, E. (2014). Teacher Beliefs about Listening in a Foreign Language. Teaching and Teacher Education, 40, 44-60.

https://doi.org/10.1016/j.tate.2014.01.007

Hamada, Y. (2015). Shadowing: Who Benefits and How? Uncovering a Booming EFL Teaching Technique for Listening Comprehension. Language Teaching Research, 20, 53-74. https://doi.org/10.1177/1362168815597504

Hamouda, A. (2013). An Investigation of Listening Comprehension Problems Encountered by Saudi Students in the EL Listening Classroom. International Journal of Academic Research in Progressive Education and Development, 2, 113-155. https://pdfs.semanticscholar.org/b811/984d6e30068a62a970b1f75b2e701e0b159e.pdf

Harmer, J. (2001). The Practice of English Language Teaching (3rd ed.). Cambridge: Longman.

Inceçay, G. (2011). Pre-Service Teachers' Language Learning Beliefs and Effects of These Beliefs on Their Practice Teaching. Procedia-Social and Behavioral Sciences, 15, 128-133. https://doi.org/10.1016/j.sbspro.2011.03.061

Johnson, K. E. (1992). The Relationship between Teachers' Beliefs and Practices during Literacy Instruction for Non-Native Speakers of English. Journal of Reading Behavior, XXIV, 83-107. https://doi.org/https://doi.org/10.1080/10862969209547763

Khuziakhmetov, A. N., \& Porchesku, G. V. (2016). Teaching Listening Comprehension: Bottom-Up Approach. International Journal of Environmental and Science Education, 11, 1989-2001. 
Kuen, Y. L., \& Embi, M. A. (2012). MUET Preparation Language Learning Strategies. Advances in Language and Literary Studies, 3, 84-93. https://doi.org/10.7575/aiac.alls.v.3n.1p.84

Kurita, T. (2012). Issues in Second Language Listening Comprehension and the Pedagogical Implications. Accents Asia, 5, 30-44.

Kutálková, K. (2017). Teacherś Beliefs in the Czech Republic: Review Study. Procedia-Social and Behavioral Sciences, 237, 1352-1358. https://doi.org/10.1016/j.sbspro.2017.02.224

Li, L. (2013). The Complexity of Language Teachers' Beliefs and Practice: One EFL Teacher's Theories. Language Learning Journal, 41, 175-191. https://doi.org/10.1080/09571736.2013.790132

Lim, T. D. (2013). Analyzing Malaysian English Classrooms: Reading, Writing, Speaking \& Listening Teaching Strategies. Masters Thesis, Seattle, Washington DC: College of Education, University of Washington.

https://digital.lib.washington.edu/researchworks/handle/1773/25020

Ministry of Education (2003). Curriculum Specifications for English Form 3.

Nur Sakinah, T., \& Nooreen, N. (2013). Relationship between Malaysian University English Test (MUET) Achievements and Trait Emotional Intelligence (Trait EI) among Matriculation Students. Graduate Research in Education (GREDUC 2013), Greduc.

Renandya, W. A., \& Farrell, T. S. C. (2011). “Teacher, the Tape Is Too Fast!” Extensive Listening in ELT. ELT Journal, 65, 52-59. https://doi.org/10.1093/elt/ccq015

Renukadevi, D. (2014). The Role of Listening in Language Acquisition; the Challenges \& Strategies in Teaching Listening. International Journal of Education and Information Studies, 4, 2277-3169. http://www.ripublication.com

Richardson, V., Anders, P., Tidwell, D., \& Lloyd, C. (1991). The Relationship between Teachers' Beliefs and Practices in Reading Comprehension Instruction. American Educational Research Journal, 28, 559-586. https://doi.org/10.3102/00028312028003559

Rose, J., \& Medway, F. J. (1981). Measurement of Teachers' Beliefs in Their Control over Student Outcome. Journal of Educational Research, 74, 185-190. https://doi.org/10.1080/00220671.1981.10885308

Rost, M. (2002). Teaching and Researching Listening (2nd ed.). Edinburgh: Pearson.

Santos, D., \& Graham, S. (2018). What Teachers Say about Listening and Its Pedagogy: A Comparison between Two Countries. In International Perspectives on Teaching the Four Skills in ELT (pp. 21-35). Cham: Palgrave Macmillan. https://doi.org/10.1007/978-3-319-63444-9 2

Spawa, C. M. C., \& Hassan, F. (2013). “I Doesn't Know English”: Beliefs and Practices in the Teaching of Speaking in ESL Classroom. Pertanika Journal of Social Sciences \& Humanities, 21, 449-460.

Tahsildar, M. N., \& Yusoff, Z. S. (2014). Investigating L2 Students' Listening Anxiety: A Survey at a Malaysian University. International Journal of Language Education and Applied Linguistics (IJLEAL), 1, 45-55. https://doi.org/10.15282/ijleal.v1.418

Tatto, M. T. (1998). The Influence of Teacher Education on Teachers' Beliefs about Purposes of Education, Roles and Practice. Journal of Teacher Education, 49, 66-77. https://doi.org/10.1177/0022487198049001008

Thomlison, T. D. (1984). Relational Listening: Theoretical and Practical Considerations. Annual Meeting of the International Listening Association.

Tobin, K., \& McRobbie, C. J. (1996). Cultural Myths as Constraints to the Enacted Sci- 
ence Curriculum. Science Education, 80, 223-241.

https://doi.org/10.1002/(SICI)1098-237X(199604)80:2<223::AID-SCE6>3.0.CO;2-I

Utami, D. N. (2016). The EFL Teachers' Beliefs And Their Teaching Practices. OKARA Journal of Languages and Literature, 10, 135-144.

http://ejournal.stainpamekasan.ac.id/index.php/okara/article/view/974

https://doi.org/10.19105/ojbs.v10i2.974

Vandergrift, L. (2007). Recent Developments in Second and Foreign Language Listening Comprehension Research. Language Teaching, 40, 191-210.

https://doi.org/10.1017/S0261444807004338

Wilkins, J. L. M. (2008). The Relationship among Elementary Teachers' Content Knowledge, Attitudes, Beliefs, and Practices. Journal of Mathematics Teacher Education, 11, 139-164. https://doi.org/10.1007/s10857-007-9068-2

Yongbai, Q. (1992). Teaching Listening Comprehension. Monday Morning: A Magazine for Language Teachers in China, 1, 17-22. 